Meta

Journal des traducteurs

Translators' Journal

\title{
The Dichotomy Free and Literal Translation
}

\section{Katharina Barbe}

Volume 41, numéro 3, septembre 1996

URI : https://id.erudit.org/iderudit/001968ar

DOI : https://doi.org/10.7202/001968ar

Aller au sommaire du numéro

Éditeur(s)

Les Presses de l'Université de Montréal

ISSN

0026-0452 (imprimé)

1492-1421 (numérique)

Découvrir la revue

Citer cet article

Barbe, K. (1996). The Dichotomy Free and Literal Translation. Meta, 41(3),

328-337. https://doi.org/10.7202/001968ar

\section{Résumé de l'article}

Le statut social de la traduction et des traducteurs varie suivant les époques et les sociétés. Aujourd'hui encore, la traduction n'est pas reconnue comme une discipline à part entière et les traducteurs et traductologues n'y sont pas pour rien. La perception de ce qu'est une bonne traduction varie elle aussi et la dichotomie traditionnelle entre traduction libre et traduction littérale peut être remise en cause. Une étude poussée, incluant les langues non indo-européennes et les cultures orales, pourrait nous aider à faire éclater cette dichotomie. 


\title{
THE DICHOTOMY FREE AND LITERAL TRANSLATION ${ }^{1}$
}

KATHARINA BARBE

Northern Illinois University, DeKalb, USA

\begin{abstract}
Résumé
Le statut social de la traduction et des traducteurs varie suivant les époques et les sociétés. Aujourd' hui encore, la traduction n'est pas reconnue comme une discipline à part entière et les traducteurs et traductologues n'y sont pas pour rien. La perception de ce qu'est une bonne traduction varie elle aussi et la dichotomie traditionnelle entre traduction libre et traduction littérale peut être remise en cause. Une étude poussée, incluant les langues non indo-européennes et les cultures orales, pourrait nous aider à faire éclater cette dichotomie.
\end{abstract}

\begin{abstract}
Historically, the status of translation and translators has changed with the ascendance of monolingualism. Even today, translation is not fully recognized as an independent field of study, and translators as well as translation theorists are not without blame for this. The requirements for a good translation vary with each text. The concepts of free and literal translation are questionable and need to be rexamined. A cross-cultural study of translation including non-Indo-European languages may help us to break out of this dichotomy, as may the study of oral cultures.
\end{abstract}

... the hermeneutically enlightened consciousness seems to me to establish a higher truth in that it draws itself into its own reflection. Its truth, namely, is that of translation. It is higher because it allows the foreign to become one's own, not by destroying it critically or reproducing it uncritically, but by explicating it within one's own horizons with one's own concepts and thus giving it new validity. Translation allows what is foreign and what is one's own to merge in a new form. (Gadamer 1976: 94)

Whenever different languages come into contact with one another, the need for translation arises. ${ }^{2}$ The extent of this need depends on the relationship between the languages, and specifically on similarities or differences of prestige, power, wealth between them. More translations take place from a prestigious into a less prestigious language, from the language of a wealthy and powerful nation into the language of a less wealthy or powerful one. Not surprisingly, the United States exports many of its cultural creations, such as literary products, TV-shows, and movies, which in their translations often influence the receptor culture. This influence is not always appreciated. Recently, a group of French intellectuals, filmmakers, and politicians attempted to stem the flow of the US-American cultural export. The resentment of American culture is not limited to France. The whole notion of cultural invasion is very prevalent all over Western Europe and is discussed in several recent newspaper articles (for example, collection of articles in Die Zeit, Nov. 1993; Rockwell in New York Times, Jan. 1994).

In the US, on the other hand, there does not exist a solid market for translations. Only about $2 \%$ of all books published in the US are translations vs. about $27 \%$ in Germany (Venuti 1993: presentation). Foreign movies, for example, are usually categorized as "art films," subtitled, and only shown in specialized movie houses. In the last five 
to ten years, only two German movies were dubbed into English, Das Boot ('Das Boot') and Männer ('Men'), merely because the producers expected some commercial success. Only rarely do translations appear on the bestseller list. A recent example is Laura Esquivel's Like Water for Chocolate (1992). The accompanying movie, even though subtitled, was more than just a critical success, since the movie also made money. Actually, recently it has been raised to the status of cult-movie. The reasons for this reluctance to accept the foreign, which some call "US-American cultural imperialism," do not concern us here directly, except to the extent that they bear on the general attitude towards translators and translations in particular in the US. ${ }^{3}$

Historically, the status of translations and translators has changed with the ascendence of monolingualism ( $c f$., for example, Bassnett-McGuire 1988; Nida 1992; Schulte and Biguenet 1992; Berman 1992). Bilingual or multilingual cultures generally hold translations and translators in higher regard than monolingual cultures. It is unfortunate that in today's predominantly monolingual US-American society, translation is deemed a secondary activity ( $c f$. Chamberlain 1992; Venuti 1992a). The low regard for translations and translators also surfaces in the academic arena. Even though, as Venuti (1992a: 2) points out, the

academy [...] is utterly dependent on translations from various languages, not merely to serve as textbooks for students, supporting curricula and canons, but to enable faculty research and university press publishing. Yet the academy has also inhibited the development of translation theory and criticism by discouraging the practice of translation, ranking it low on the scale of scholarly value and degrading it during reviews for contract renewal, tenure, and promotion.

Furthermore, between 1968 and 1990 five English writing authors have won the Nobel Prize. 4 However, regardless of the language background of the writers under consideration, the committee reads each work in English, which means that, in most cases, they read translations. Translators are obviously not highly regarded, except in their own circles (like the American Translator's Association, ATA). And yet, everybody who reads more than one language knows what a poor translator can do to a successful source language text.

Similarly, reviewers typically praise the writings of authors in translation by commenting on their crisp, clean style. They usually do not acknowledge that the style is at least partly created by the translator. Reviewers, who typically have not read the original, frequently only refer to the translator if they find fault with the text, with comments like "The translator did not capture the mood/the essence" or "The translator's style is flawed," etc. (Venuti 1993: presentation). So, what are the requirements for a good translation? Blanchot (1990: 83) points to two opposing ideas:

[O]ne either says of it that it does not read like a translation, or one marvels at just how identical it is with its original, how it is truly one and the same work; but in the first case one effaces the origin of the work to the advantage of the new language, and in the second case, one effaces the originality of either language to the advantage of the work; in both cases, something essential gets lost.

Blanchot's two types of translation clearly demonstrate the dichotomy of free and literal translation, fundamental to so much of western thought on translation. This dichotomy still appears at the basis of most if not all translation discussions, even if it is not overtly expressed. The fundamental bias is that this opposition exists, and that we just need to find its proper application and distribution. I believe this to be a false dichotomy, which is based on two different concepts, as I will clarify in this chapter. 
In summary, the discussion in translation studies then revolves around two main topics. The first is the position of the discipline as an independent field of study, apart from either comparative literature or applied linguistics. It is fair to say that translation studies as a discipline are still not fully recognized. Translators and translation theorists are partly to blame for this problem as I shall show. The study of translation is particularly important because through it we can evaluate the relationship among languages and learn more not only about the source but also about the target language (Benjamin 1973: 186, and many others). The second predominant question is whether translation should be source language oriented (literal) or target language oriented (free). Therefore, in the following, I want to re-examine this dichotomy.

\section{TRANSLATION: A SECONDARY ACTIVITY?}

The low and secondary status experienced by translations, translators, and translation studies is partly due to the translators' and theorists' bias towards the superiority of the original as something pure, unattainable, unreachable. Predominantly negative metaphors describe the translators' activities, to wit, the famous Italian Traddutore - Traditore ('translator - traitor'), as well as the description of the process of translation as rape, violence, or injustice done to the original. It seems unnecessary to view a common practice like translation, in such a negative light, even though it is true that in terms of order of creation, the original comes first and its translation later.

Now there exists a paradox in the way our culture looks at past and future, first and later, which is relevant to the consideration of translation. On the one hand, first is better and later worse, particularly in areas like sports. On the other hand, we also believe in progress, i.e., later is better because improved. While we look towards the future for fulfillment, improvement, progress, we also nostalgically glorify the past as purer and better.

Why do we denigrate the action of the translator and thereby make it so difficult? Without question, a translation can never be exactly like its original. Obvious differences in language, audience, and cultural circumstances see to that. And yet, translations have variously been enjoyed, rejected, even appropriated as part of the TL cultural heritage. ${ }^{5}$ In countless instances, they have influenced the TL-culture, founded the basis of the development of a written language, influenced TL literary practice, or even found their place in the TL literary canon ( $c f$. Heylen 1993). But nevertheless, the inviolability of the original is assumed.

The prestige of the SL influences the view of the original. If the original appears in a SL that is revered due to a variety of reasons (original's language is purer, less influenced by decadent Western values, or original's language is no longer spoken and achieves a classic status, or the original's language is considered sacred) then the translation will attempt to stay close to the language (literal). If, however, the SL is not prestigious, one may even consider the translation an improvement of the original (free). These same thoughts are usually not present when we are confronted with translations inside a single language of once accessible texts that are now no longer linguistically accessible (e.g., modernizations of Chaucer). These texts constitute part of our cultural heritage and are always held in high regard. An obvious bias presents itself here and appears connected to the debate literal/free translation.

\section{LITERAL - FREE TRANSLATION}

"[T]he distinction between word for word and sense for sense translation, established within the Roman system, has continued to be a point for debate in one way or another 
right up to the present" (Bassnett 1988: 39). Writers may use different terminology but the concepts appear to be the same. Even those translation theorists who feel that they have broken out of the dichotomy, have usually given this dichotomy their own terminology or, perhaps, following Dryden (1680) or Goethe (1819), proposed a three-way division.

In his Sendbrief zum Dolmetschen (1530) ('Circular Letter on Translation'), Luther advocated a type of translation which is sensitive to the original but also available to a large TL-audience and not just to the educated elite. Luther not only knew the language of the elite (Latin), he also knew how to reach and challenge the "mother in the house, the children in the streets, the common man in the market" (my translation, Luther 1969: 21, original quote always in endnote). ${ }^{6}$ In his translations he seems to have negotiated each word or phrase separately, opting for a different mixture of free and literal translation in each one. There is no doubt that he influenced the development of German. Luther let himself be guided by the SL into expanding the German lexicon, predominantly with new collocations, while simultaneously translating according to the language of the people (vernacularizing). ${ }^{7}$

Dryden (1680) attempts to expand the dichotomy using different terminology. $\mathrm{He}$ uses the term metaphrase to mean literal, word-for-word translation, and his term "paraphrase, or translation with latitude" (in Lefevere 1992: 102), roughly corresponds to free, sense-by-sense translation. He adds imitation, where the translator uses the original as a basis, in order to create a work that the SL-author would have created, had he been a contemporary English speaker.

Schleiermacher also identifies imitation, but in his framework imitation is not a type of translation. ${ }^{8}$ He differentiates between translation [1] and imitation or paraphrase [2] in his famous and often cited statement: "Either the translator leaves the author in peace, as much as possible, and moves the reader towards him [1]. Or he leaves the reader in peace, as much as possible, and moves the author toward him [2]" $(1992: 149) .{ }^{9}$ That si to say, in the first case [1], if the TL-reader knew as much of the Source Language as the translator knows about the Source Language then he/she would have translated the text just as the translator did. The second case [2] is achieved either by Paraphrase ('paraphrase') or Nachbildung ('imitation'), hence, the foreign author, were he/she not foreign, would have written the work in the Target Language just as the translator translated it.

With Schleiermacher, the dichotomy free and literal finds a different application. The translator in Schleiermacher's first choice, [1], who as Blanchot (1990: 85) so aptly puts it is 'an eternal guest' in the original, can either stay closer to the SL-text (literal) or move further away (free). Schleiermacher considers only [1] to be translation per se, where nuances of the foreign appear, because a translator attempts to convey the foreign as he/she as a foreigner perceives it. Thus the TL can only change or be influenced by means of translation, never due to imitation. It goes without saying that Schleiermacher advises against any type of mix of the two approaches, [1] and [2].

Paraphrase and imitation, Schleiermacher's second option, [2], however, signify "pre-translation" stages. Schleiermacher envisions a cycle: First, a SL-text is imitated to awaken general interest in the foreign, a paraphrase then prepares widespread understanding and, finally, translation per se succeeds. Translation is important because "we should not fail to acknowledge that much of what is beautiful and powerful in our language has in part either developed by way of translation or been drawn out of obscurity by translation" (1992: 165).10 Schleiermacher thus acknowledges the importance of translation for language renewal.

Like Schleiermacher, Benjamin also expands the usefulness of translation, stating that "the kinship of languages is brought out by a translation far more profoundly and 
clearly than in the superficial and indefinable similarity of two works of literature" (Benjamin in Arendt 1969: 72-73).11 Thus, translation not only shows the relationship between languages, it also teaches translators and readers about their own language and not just about the SL. In the TL, a translation takes on a new life, separated from the original. TL-text and original are inherently different. " $[N]$ o translation would be possible if in its ultimate essence it strove for likeness to the original" (ibid.: 73), 12 Benjamin writes in his famous article Die Aufgabe des Übersetzers ('The Task of the Translator'), which forms the basis of many other musings on translation (Derrida 1985; de Man 1986). ${ }^{13}$ A translation takes on its own life in the TL. The traditional dichotomy Treue, (here: literal) and Freiheit (here: free) cannot be of use in a theory of translation that attempts more than Sinnwiedergabe ('reproduction of meaning'). Literal translation, too bound to the single word, can only rarely reproduce the sense or meaning. In addition, even the most free translation cannot capture that what is there but not communicable, i.e., the essence, because it moves away too far from the word, and the word is still the basis of translation. Hence, neither approach holds any usefulness for a satisfactory translation theory.

That said, Benjamin, nevertheless, seems to favor literal translations, as he declares that the "interlinear version of the Scriptures is the prototype or ideal of all translation" (Benjamin in Arendt 1969: 82). Under the influence of Latin, which was not only prestigious but also considered sacred by the religious and secular powers, scholars produced early interlinear versions. These scripture texts are prime examples of a pure word-for-word approach. The translation was written right into the original, between the lines. However, these works were accessible only to a very small number of highly educated men, who knew both languages. Nowadays, we encounter this approach in the glossaries of linguistic field notes.

A practical consideration: who would want to read these Benjaminian "ideal" translations? This type of translation can only reach a very small number of scholars who also read the SL. According to Schleiermacher's theory, Benjamin's ideal translation does not constitute a translation. A translation should be accessible to those readers who do not know the SL. If we all knew all languages, translation would be unnecessary. ${ }^{14}$ And on an even more practical level, translation happens to disseminate knowledge, ideas, beautiful expressions, etc. Authors want to be widely read, in part because of their ideas, in part also because of economic concerns. We have to combine our ideals with reality, because Babel is still with us.

Recently, the discussion of literal or free translation took a new turn, looking at the requirement of the text. Wilss (1982: 113) proposes that the old problem of SL or TL-related translation has disappeared, "giving way to a new concept of the goal of translation aiming at a functional integration of the SL author, the SLT [source language text], the translator and the TLT recipient." Wilss translates his German book title Übersetzungswissenschaft as the 'science of translation.' Wissenschaft in German includes the so-called natural or hard sciences, but also humanities and social sciences. The "science" of translation is a value-judgment science. It is unfortunate that translation studies has to be called a science to gain legitimacy. The 'science of translation' sets out to (1) acquire objective data, (2) understand the actual process of translation and (3) discover the function of whatever it is that is involved in translation (Wilss 1982: 65). It is easier to train translators to do translations for special purposes (e.g., very limited and technical) than for literary texts. Wilss' "new" outlook, however, does not seem to contradict the traditional two-way distinction. Wilss shifts the distinction onto another level, to one of genre, with poetry on the one end of the spectrum and "scientific" texts on the other side. 15 
Each text now has a place on a textual continuum, which goes along the lines of literal/free. Thus Snell-Hornby (1988: 32) differentiates between three types of translation and their associated texts:

\begin{tabular}{cllll} 
Literary & & General & \multicolumn{2}{c}{ Special Language } \\
Bible Stage/ & Lyric Modern & Newspaper Advertising Legal Economic Medicine & Science/ \\
Film & Poetry Lit. & Gen. Info Language Lang. Language & Techn.
\end{tabular}

She acknowledges that "prototypically literary devices such as word-play and alliteration... [as well as] prototypically technical terms from the language of science" (ibid: 33 ) can also be found in special or literary language texts, respectively. It is assumed that translators translate the right side of Snell-Hornby's continuum more literally, following the words more closely, and the left side more freely. However, some academic translators want the left side also translated more literally, to avoid losing the foreign flair and, consequently, to be able to experience the foreign (Berman 1992). Lefevere (1993) recently proposed a similar distinction into three different types of discourses: the discourses of scientific, of general, and of literary realms.

These continua have definite merits in the teaching of translation. The beginning translation student will find these categories very satisfying. But it will soon appear that these distinctions are not discrete, and the satisfaction may disappear. Thus, we still have not found a way out of the dichotomy. Even Benjamin, who doubts their usefulness, nevertheless uses the distinction free-literal. All other writers have basically stayed within these boundaries.

\section{FOREIGNIZING - DOMESTICATING}

Recently, the conjunction of the terms foreignizing and domesticating has been suggested, ostensibly to supercede the dichotomy literal and free translation (Van den Boek 1981; Venuti 1992). I find many problems with this terminology. When we speak about foreignizing and domesticating, our basis is in the former case the TL-text (foreignizing) and in the latter the SL-text (domesticating). But as Rosenzweig (1926/1936: 93, my translation) commonsensically points out, "all translation happens into the language of the reader and not into the language of the original." 16 Hence, the goal in a translation is always some type of domestication, i.e., a translator translates the SL-text into the TL with the primary goal to provide access to a text/work/conversation to readers/speakers who would otherwise have none.

Perhaps, if we do not see it in opposition to domesticating, the idea of foreignizing may have its merits, too. In terms of differences between SL and TL culture, foreignizing or rather keeping the foreign has the goal to open up vistas, thus removed from the realm of translation. The ideal translation then is a translation that lets the reader experience the foreign without discouraging him/her from reading because of linguistic incaccessibility of the TL version. Thus the idea of foreignizing is closely linked to the perceived US cultural imperialism and to xenophobic tendencies in the US. 17

In connection with translation, however, foreignizing seems to be a misnomer. A foreignizing translation does not foreignize itself so much as the TL, that is the goal, for the TL to be more open to other cultures. But foreignizing could only apply if we first translate a text, domesticate it if you will, and then rework the translated text in order to make it foreign. Only a text that already exists in a language can be foreignized. Of course, the implication of foreignizing is that a translation should stay close to the SL, 18 which then contitutes another way of describing a free translation, perhaps Schleiermacher's translation [1]. The dichotomy domesticating-foreignizing sounds very appealing but is ultimately not very useful in describing what to do with a text. 
Foreignizers also believe that translations constitute one locus of change in a TL. They want to "explode" perceived language boundaries. But they can only attempt to do so because languages have been "exploding" on their own all along. Every spoken language has in it the potential for its own renewal. ${ }^{19}$ Regularly, languages change, not only under the influence of the foreign (in philology we find the terms sub- or superstratum effect to explain some major reasons for these changes) but also on their own account. This internally driven change even becomes evident in one's own life time. There are generational differences, differences due to education, economic status, or geographical location. Any socio-linguistic study will give evidence of these changes (see, for example, Labov 1972 on language change).

Thus speakers do not necessarily only look outside the language for renewal. Speakers/writers use original or nonce metaphors, or newly coined collocations in an attempt to express their sentiments more accurately or in a fresh way. Literature, especially poetry, constantly foreignizes often without the actual influence of the foreign. Klopstock, for example, formed many new terms from German stock without influence of the foreign, and so did the DADAist Schwitters. In particular, in his well-known poem "Anna Blume', he "plays" with and "explodes" the language apparently under the influence of his own imagination, and "his own delight in verbal nonsense" (Elderfield 1985: 37).

\footnotetext{
Anna Blume

Oh Du, Geliebte meiner 27 Sinne, ich liebe Dir!

Du, Deiner, Dich Dir, ich Dir, Du mir, - wir?

Das gehört beiläufig nicht hierher!

Wer bist Du, ungezähltes Frauenzimmer, Du bist, bist Du?

Die Leute sagen, Du wärest.

Lass sie sagen, sie wissen nicht, wie der Kirchturm steht.
}

Eve Blossom

O thou, beloved of my twenty-seven senses, I love thine!

Thou thee thee thine, I thine, thou mine, we?

That (by the way) is beside the point!

Who art thou, uncounted woman,

Thou art, art thou?

People say, thou werst,

Let them say, they don't know what they are talking about.

(ibid:: 37)

Here a further feature, archaizing, comes into play ( $c f$. Bassnett-McGuire 1988). Schwitters uses old pronouns of address in his own English version to show the different cases of the German pronoun.

Hence foreignizing appears to be an intellectual illusion. A translator always stays within the boundaries of the TL. He/she could not expect to find an audience for a translation that follows closely the grammar of the SL and makes the translation seem "grammatically incorrect." On the other hand, the introduction of new terms (metaphors, collocations, etc.) coined within the TL on the basis of the SL does not necessarily impede understanding, even though it may take some effort to understand.

Changes to the grammatical system of a language, for example, in the areas of conjugation or declension, adjective endings, or noun-plurals of a TL by means of a translation have, as far as I know, never been attempted.

For to be sure, the fact that one can never depart too far from linguistic conventions is clearly basic to the life of language: he who speaks a private language understood by no one else, 
does not speak at ail. But on the other hand, he who only speaks a language in which conventionality has become total in the choice of words, in syntax, and in style forfeits the power of address and evocation that comes solely with the individualization of a language's vocabulary and of its means of communication. (Gadamer 1976: 85-86)

The translator would perhaps be accused of an insufficient knowledge of the TL, unless he/she translate into a dialect of the TL. This is not to say that grammatical changes cannot occur under the influence of a translation, we know that Latin had a great influence on German. But grammatical changes take a long time to happen and can often only be observed once they are completed. ${ }^{20}$ Lexical changes, like additions to the lexicon, can be observed. Thus a successful translation can have an influence on the pragmatic use of the language, perhaps, by means of loan-translations, or by amending or changing the meanings of words. This is what happened in German, which over the centuries tolerated many different foreign influences, from Latin to French to American English today.

\section{FINAL THOUGHTS}

The untenability of the translation dichotomy furthermore supports Fish's contention that the dichotomies connected to immediacy and remove have at the very least to be reconsidered. On the basis of the SL the literal exemplifies closeness and immediacy, and the free exemplifies distance. "[T]he first or left-hand term stands for a mode of knowing that is, at least relatively if not purely, direct, transparent, without difficulties, unmediated, independently verifiable, unproblematic, preinterpretive, and sure; and conversely, that the mode of knowing named by the right-hand term is indirect, opaque, context-dependent, unconstrained, derivative, and full of risk" (Fish 1988: 41). We have seen in the discussion of irony so far that only irony's presence or absence can be debated but not its immediacy or distance.

Traditionally, the literal approach to translation has often been located in the domain of scientific, technical texts, i.e., texts which supposedly would not allow metaphors or irony. Literal translation was seen in contrast to free translation, which was seen as preferable in the translation of poetry, literature, and texts which allow metaphors, irony and the like. Interestingly, throughout translation history, the literal translation approach has also beem applied to the domain of literature in order to maximize the experience of the foreign (Berman 1992). Thus, Hölderlin and Rosenzweig advocate translating while staying close to the foreign. The question now is whether such a translation is really literal or foreign at all, because the TL accepts this type of translation. Moreover, the translation can also be understood as simultaneously free in the TL because it attempts to stay free from constraints the TL may impose (this is also the basis for foreignizing).

No text dictates its means of translation, only forces outside the text do (publishers, intended readers, economics, etc.). These external requirements change along with time, fashion, and advances in science, so that, with the change of a culture new metaphors appear. Nevertheless, it is obvious that translation requirements change with each text.

Literal and free represent only rather inaccurate and questionable descriptive terms, and do not constitute a real distinction. A cross-cultural study of translation including non-Indo-European languages may help us to break out of this dichotomy, as may the study of translation in oral cultures.

[W] hen translation is properly understood as something more than mere decoding, we realize that it suggests... other ways of being in the world. (Tyler 1978: 70) 
Notes

1. I want to thank Wolfram Bublitz, Catherine Jagoe, Wendell Johnson, and Adriana Menassé for their many helpful suggestions. This paper also owes much to discussions with fellow participants and invited speakers at the 1993 NEH Institute on Translation at SUNY Binghamton.

2. I am talking here about languages that have already been written down. But I also think that it would be fascinating to study the position and realization of translation in primarily oral cultures as BassnettMcGuire suggests (1988: 133).

3. For more reading on US cultural dominance and related topics see for example, E. T. Hall (1959) and A. Omaggio (1993).

4. At the NEH Institute, Joachim Neugroschel, translator of Nobel Laureate Elias Canetti, pointed out this phenomenon.

5 For a long time as a child, I considered Shakespeare to be a German writer.

6. "[M]an muß die Mutter im Hause, die Kinder auf der Gassen, den gemeinen Mann auf dem Markt drum fragen, und denselbigen auf das Maul sehen, wie sie reden und darnach dolmetschen" (Luther in Störig 1969: 21)

7. More recent translations of the Old Testament, e.g., by Buber and Rosenzweig (1926) in German or Everett Fox in English seek to maintain as much as possible the character of the SL Hebrew as well as certain oral devices of Hebrew (in particular, the use of Leitwörter).

8. Schleiermacher has been credited to be the first to pursue an in-depth study of translation (Lefevere 1992; Berman 1984/1992). He approaches the study of translation, giving it the status of a Wissenschaft ('discipline'), namely Übersetzungswissenschaft ('discipline of translation'), somehow broader than others, as a hermeneutics. Übersetzungswissenschaft was unfortunately mistranslated into 'The Science of 'Translation' (Wilss 1982). Wissenschaft includes Geisteswissenschaft 'humanities' as well as Naturwissenschaft 'sciences'. Lefevere's term 'Translation Studies' covers Schleiermacher's idea far better.

9. Schleiermacher (in Störig 1969: 47) writes "Entweder der Uebersezer läßt den Schriftsteller möglichst in Ruhe, und bewegt den Leser ihm entgegen; oder er läßt den Leser möglichst in Ruhe und bewegt den Schriftsteller ihm entgegen."

10. Wir dürfen 'nicht verkennen, daß viel schönes und kräftiges in der Sprache sich erst durch das Uebersezen theils entwikkelt hat, theils aus der Vergessenheit ist hervorgezogen worden' (1813/1973: 70).

11. In der Wahrheit aber bezeugt sichdie Verwandtschaft der Sprachen einer Übersetzung weit tiefer und bestimmter als in der oberflächlichen und undefinierbaren Ähnlichkeit zweier Dichtungen (in Störig 1969: 185-186).

12. ... keine Übersetzung [wäre] möglich..., wenn sie Ähnlichkeit mit dem Original ihrem letzten Wesen nach anstreben würde (in Störig 1969: 186).

13. Both English translations of Benjamin's article appear to have serious flaws and one would wish for a new translation. It is perhaps ironic that most subsequent writings on Benjamin happen to be based upon those translations (English and French) and not on the original. Benjamin's dense and complicated text seems to defy one interpretation. With each reading new viewpoints appear. This is, partly, why the article still fascinates so many readers.

14. If translation is no longer needed, Babel would be overcome.

15. I do not question that each text has its own particular translation requirements, I merely question the substitution of "poetic-scientific" for free-literal.

16. 'schließlich geschieht alles Übersetzen in die Sprache des Lesers und nicht in die Sprache des Originals' (Rosenzweig 1926/1936: 93)

17. See Omaggio (1986) for a discussion of cultural attitudes towards a second language in the US.

18. This somehow became some intellectuals' and academics' ideal.

19. I see spoken language here as any language in use, i.e., not either dead (no longer spoken but known descendants exist) or extinct (no known descendants exist).

20. Sapir (1921) already speaks about the disappearance of whom. Many of my students now do not know when and how to use whom anymore, even though they have no trouble understanding when whom is used.

\section{REFERENCES}

BASSNETT-MCGUIRE, Susan (1988) : Translation Studies, London, Routledge.

BENJAMIN, Walther (1969) [1923] : "Die Aufgabe des Übersetzers" Störig, Hans-Joachim (Ed.), Das Problem des Übersetzens, pp. 182-195, [translated by Harry Zorn in Arendt, Hannah (Ed.), 1969, Illuminations, New York, Schocken Books, pp. 69-82.]

BERMAN, Antoine (1992) [1984] : The Experience of the Foreign, translated by S. Heyvaert, Albany, SUNY Press.

BLANCHOT, Maurice (1990) [1971] : "Translating", translated by Richard Sieburth, Sulfur, 26, pp. 82-86.

CHAMBERLAIN, Lori (1992) : "Gender and the Metaphorics of Translation", Venuti, L. (Ed.), Rethinking Translation: Discourse, Subjectivity, Ideology, London, Routledge, pp. 57-74. 
DERRIDA, Jacques (1985): "Des Tours de Babel", translated by John F. Graham, John F. Graham (Ed.), Difference in Translation, Ithaca, Cornell University Press, pp. 165-208.

DRYDEN, Joseph (1992) [1680] : From the preface of his translation of Ovid's Epistle, Lefevere, A. (Ed.), Translation/History/Culture: a Sourcebook, London, Routledge, pp. 102-105.

ELDERFIELD, John (1985) : Kurt Schwitters, New York (NY), Thames and Hudson.

FISH, Stanley (1988) : Doing what Comes Naturally, Durham (NC), Duke University Press.

GADAMER, Hans-Georg (1976) [1972] : Philosophical Hermaneutics, translated and edited by David E. Linge, Berkeley, University of California Press.

GOETHE, Johann Wolfgang (1969) [1819] : "Drei Stücke vom Übersetzen", Störig, H.-J. (Ed.), Das Problem des Übersetzens, pp. 34-37.

HALL, E. T. (1976) : Beyond Culture, Garden City (NY), Anchor Press.

HEYLEN, Romy (1993): Translation, Poetics and the Stage, London, Routledge.

LABOV, William (1972) : "On the Mechanisms of Linguistic Change", Gumperz, John and Dell Hymes (Eds.), Directions in Sociolinguistics: The Ethnography of Communication, New York, Holt, Rinehart and Winston.

LEFEVERE, Andre (Ed.) (1992) : Translation / History/Culture: a Sourcebook, London, Routledge.

LUTHER, Martin (1969) [1530] : "Sendbrief vom Dolmetschen", Störig, H.-J., Das Problem des Übersetzens, pp. 14-32.

MAN, Paul de (1986) : The Resistance to Theory, Minneapolis, University of Minnesota Press.

NIDA, Eugene (1991): "Theories of Translation", Traduction terminologie rédaction (TTR), vol. 4/1, pp. 19-32.

OMAGGIO, Alice (1993) : Teaching Language in Context, Boston (Mass.), Heinle \& Heinle.

ROCKWELL, John (1994) : "The New Colossus: American Culture as Power Export", New York Times, $1 / 10 / 1994$

ROSENZWEIG, Franz [1926/36] : "Die Schrift und Luther", Martin Buber and Franz Rosenzweig, Die Schrift und ihre Verdeutschung, Berlin, Schocken, pp. 88-129.

SCHLEIERMACHER, Friedrich (1969) [1813] : "Methoden des Übersezens", Störig, H.-J., Das Problem des Übersetzens, pp. 38-70, [translated in Lefevere 1992, pp. 151-166]

SCHULTE, Rainer and John BIGUENET (1989): The Craft of Translation, Chicago, University of Chicago Press.

SNELL-HORNBY, Mary (1988) : Translation Studies: An Integrated Approach, Amsterdam, John Benjamin.

STÖRIG, Hans-Joachim (Ed.) (1969) : Das Problem des Übersetzens, Darmstadt, Wissenschaftliche Buchgesellschaft.

TYLER, Stephen (1978) : The Said and the Unsaid, New York, Academic Press.

VAN DEN BOEK, Raymond (1981): "The Limits of Translatability Exempliflied by Metaphor Translation", Poetics Today, 2/4, pp. 73-87.

VENUTI, Lawrence (Ed.) (1992a) : Rethinking Translation: Discourse, Subjectivity, Ideology, London, Routledge.

VENUTI, Lawrence (1992b) : "Review", Textual Practice, 6:2, pp. 316-324.

WILSS, Wolfram (1982): The Science of Translation, Tübingen, Gunter Narr 